\title{
Al atisbo de las analogías. La formación del método neobarroco en José Lezama Lima y Severo Sarduy
}

\author{
María José Rossi \\ UBA, Fac. Soc., IEALC \\ majorossi@hotmail.com \\ Recibido 20/06/2018 \\ Aprobado 27/07/2018
}

\section{Resumen}

En el año 1957, el escritor cubano José Lezama Lima pronuncia una serie de conferencias en el Centro de Altos Estudios del Instituto Nacional de Cuba que luego se recopilan y editan bajo el nombre de La expresión americana. Fundacionales respecto del fenómeno estético-político denominado 'neobarroco', cuyo canon Severo Sarduy se encargará de compendiar y conceptualizar ${ }^{1}$, estimamos que esos ensayos esbozan una teoría de la lectura estrechamente ligada al mundo de habla hispana (por lo general, relegado del mundo filosófico) que aún se encuentra en ciernes. Es por eso que, a partir de su inspiración, el cometido de este artículo es sentar las bases de una hermenéutica neobarroca anclada en territorialidad americana. Para Lezama, ese territorio privilegiado es Cuba; pero también lo son las innumerables lecturas y las imágenes vivientes de una tradición que componen, por la fragua candente del propio Lezama, un concierto que las torna contemporáneas. La vivencia oblicua del objeto amado, casi siempre elidido o ausente, llevará al autor de Paradiso a esbozar un dispositivo de lectura y un método de composición mitopoético nacido de su propia imaginación creadora, con el cual trazar enlaces metafóricos impensados entre objetos culturales diversos, ya se trate de lienzos, leyendas orales, íconos o textos. Un método que cuaja en una territorialidad impura, proclive a las contaminaciones, pletórica de

\footnotetext{
${ }^{1}$ Severo Sarduy, El barroco y el neobarroco, Buenos Aires, Cuadernos del Plata, 2011.
} 
voces propias y prestadas, siempre susceptible a experimentar metamorfosis. No importa lo distantes en el tiempo en que se encuentren o las fronteras que separen a esos objetos: será la potencia de ciertas imágenes primordiales y el ingenio del sujeto metafórico, capaz de encontrar analogías que se hurtan al sentido común, las que aproximen lo distinto. Pero esa imaginación portentosa no es sin asidero, como pudiera parecer a primera vista. Las páginas que habremos de comentar revelan una lectura muy atenta de aquellos autores de amplia circulación entre los años 40 y 50, y que sirven para enmarcar una propuesta hermenéutica original y una teoría de la lectura que incluye la escritura como momento propio (de ahí la referencia a la composición mitopoética).

Considerando a Lezama un precursor, e inspirado en premisas posestructuralistas en boga por los años 70, Sarduy retoma las premisas de ese método al que, no obstante, transforma. La marca del maestro subsiste pero el ímpetu de las analogías se renueva. En tal sentido, Barroco y neobarroco será el texto que condense las premisas del método sarduyiano, su propio dispositivo de lectura. Ese método recibe el nombre de retombée, en el que la analogía entre elementos distantes, base del comparatismo de Lezama, se retoma con nuevos bríos. Diseminado a lo largo de algunos de sus principales ensayos, las connotaciones estético-políticas del concepto de retombée proyecta el ímpetu de la contraconquista como expresión del barroco en América. Nos referiremos a esa proyección estético-política en nuestras conclusiones.

PALABRAS CLAVE: Lezama Lima, Severo Sarduy, hermenéutica, método, analogía

\section{Abstract}

In 1957, the Cuban writer José Lezama Lima gave a series of lectures at the Center for Higher Studies of the National Institute of Cuba, which were later compiled and edited under the name of La expresión americana. We estimate that these essays outline a theory of reading closely linked to the Spanish-speaking world (generally 
relegated from the philosophical world) that is still in its infancy. The purpose of this article is to lay the foundations of a neo-baroque hermeneutic anchored in American territoriality. For Lezama, that privileged territory is Cuba; but so are the innumerable readings and the living images of a tradition that make up a concert that makes them contemporary. The oblique experience of the beloved object, almost always elided or absent, will lead the author of Paradiso to outline a reading device and a method of mythopoetic composition. The oblique experience of the beloved object, almost always elided or absent, will lead the author of Paradiso to outline a reading device and a method of mythopoetic composition with which to draw metaphorical links unthinkable among diverse cultural objects, whether canvases, oral legends, icons or texts. No matter how distant in time they are or the boundaries that separate those objects: it will be the power of certain primordial images and the ingenuity of the metaphorical subject, capable of finding analogies that steal from common sense, those that approximate the different. But that portentous imagination is not without a handle, as it might seem at first sight. The pages that we will comment reveal a very attentive reading of those authors of wide circulation between the $40 \mathrm{~s}$ and $50 \mathrm{~s}$, and that serve to frame an original hermeneutical proposal and a theory of reading that includes writing as a moment of its own (hence the reference to the mythopoetic composition).

Considering Lezama as a precursor, and inspired by post-structuralist premises in vogue in the 70s, Sarduy takes up the premises of that method which, however, transforms. The mark of the teacher subsists but the impetus of the analogies is renewed. In this sense, Baroque and neo-baroque will be the text that condense the premises of the Sardinian method, its own reading device. This method is called retombée, in which the analogy between distant elements, the basis of Lezama's comparatism, is taken up with new vigor. Disseminated throughout some of his main essays, the aesthetic-political connotations of the concept of retombée project the impetus of the counterconquest as an expression of the baroque in America. We will refer to that aesthetic-political projection in our conclusions.

KEY WORDS: Lezama Lima, Severo Sarduy, hermeneutics, method, analogy 


\section{1.a. Lezama Lima: contrapuntos y polifonías}

“Mito y cansancio clásico", es la primera de una serie de conferencias que José Lezama Lima pronuncia en enero del año 1957 en el Centro de Altos Estudios del Instituto Nacional de Cuba y que serán publicadas ese mismo año bajo el título La expresión americana ${ }^{2}$. Vista a la luz de la revolución cubana y de los movimientos literarios y libertarios que, por esa época, pugnan por encontrar lo propiamente americano en la expresión (ya sea lingüística o política, o mejor, lingüístico-política, indiscernibles, como lo es, al menos, para Lezama), esa conferencia inaugural arremete contra la fatiga que aqueja a los contemporáneos europeos y a la que la chispa del "señor barroco" americano opone el genio de su creatividad y su inventiva. "Horno trasmutativo de la asimilación", como lo llamará, ese barroco retorna en América a su condición volcánica, al plutonismo y la tensión que supieron caracterizarlo ${ }^{3}$. Pero esta operación no es sin rigor, presupone un proceder que la erudición lezamiana convierte en método. Sin embargo, es un método que se nos da por escorzos. Lezama no pretende teorizar sobre el mismo, ni hay una formulación que preceda a su aplicación, conforme a la vocación aplicativa de la hermenéutica. La potencia de las imágenes evocadas por nuestro autor y la multiplicidad de referencias eruditas, obnubilan muchas veces lo que no obstante obedece a una reflexión profunda acerca de la tradición literaria, artística e incluso filosófica, tanto europea como latinoamericana. Lezama no nos esconde sus fuentes, dialoga con sus contemporáneos, toma posición. Y con todos esos elementos compone una obra de orfebre en la que entreteje su visión, no sólo del arte o la literatura en general sino, sobre todo, su valoración y su gusto de lo singular (un soneto, una miniatura, una estatuilla). Lezama paladea sus objetos, disfruta de ellos, su estética es finalmente una propuesta gastronómica de sabores varios y mezclas audaces que se concreta en banquetes y, por qué no, en bacanales, donde lo que cuenta es el placer. Pese a la aparente fragmentación, esos singulares son reunidos por hilos sutiles que componen una trama compleja hecha de nudos, agujeros y pespuntes. Así es la escritura báquica de Lezama. Por eso, su 'obra

\footnotetext{
2 En José Lezama Lima, Ensayos barrocos. Imagen y figuras en América Latina. Buenos Aires, Colihue, 2014, pp. 211-368.

3 José Lezama Lima, “La curiosidad barroca”, op. cit., 228.
} 
completa' es aún una obra (si es que aún puede seguir llamándose así) in progress (de hecho ninguna de sus dos únicas novelas, Paradiso (1972) y Oppiano Licario (1977) ${ }^{4}$, tiene un final, y la segunda es continuación de la primera), que aún seguimos escribiendo, una escritura que se ofrece al goce de los sentidos y se presta a la fiesta del pensamiento. A pesar de los rodeos, los injertos, las volutas y las interferencias, a pesar de los claroscuros que animan su texto, característica de toda escritura que se concibe como barroca hay, con todo, una partitura, una guía que orienta los contrapuntos y compone esta trama que es a la vez sonora, visual y textual.

Sin pretender (aunque probablemente sin conseguirlo) romper con el alma lezamiana que recusa la camisa de fuerza de los academicismos, en el curso de este artículo nos abocaremos a este texto inaugural que sirve de punto de partida y de condensación de un dispositivo hermenéutico con el que Lezama descubre, no sólo una manera de obtener sentido y significado, sino de forjar una filosofía de la historia cuyos periplos recibirán el nombre de "eras imaginarias" ${ }^{5}$. Un método que Lezama expone, como hemos dicho, no de manera apriorística, sino en su desarrollo. Un método que se despliega en el decurso mismo de su aplicación, que Lezama no despega de la materialidad de las obras a las que se aboca, y que sugiere así, anticipadamente, que un dispositivo anclado en la inmanencia, como se ha sugerido en otro lugar ${ }^{6}$, no puede deslindarse de lo que cada textualidad significante, en su singularidad (ya se trate de un ensayo, una pintura o un film), propone para su desciframiento.

Lezama no rehúye el rigor para la comprensión del devenir histórico, pues no hay, en sentido estricto, Historia, sino devenir histórico, cuya comprensión es el destinatario final de su cometido hermenéutico. De lo que se trata es de proponer, para América, otra historia posible. Pero su modo de abordarla se distingue del que adoptan los historiógrafos contemporáneos: Oswald Spengler (en boga por aquellos

\footnotetext{
${ }^{4}$ José Lezama Lima, Paradiso, Buenos Aires, ediciones de la Flor, 1968. Oppiano Licario, Edición de César López, Madrid, Cátedra, 1989.

5 José Lezama Lima, "Preludio a las eras imaginarias”, en Ensayos barrocos, op. cit., p. 151.

${ }^{6}$ María José Rossi. "La errancia como método: la noche de Jacques Rancière", en Nuevo Itinerario, Revista digital de Filosofía, Septiembre 2017, pp. 124-135.
} 
años), T. S. Eliot, Arnold Toynbee. "Nuestro método quisiera más acercarse a esa técnica de la ficción, preconizada por Curtius, que al método mítico crítico de Eliot", señala ${ }^{7}$ Y el gabinete de lectura de Lezama comienza a darnos las primeras pistas. Lezama no nos escamotea sus fuentes, sólo que, al eludir cualquier intento de exposición pedagógica, nos invita a dar un rodeo. En tal sentido, cada mención de las fuentes no resulta sin su correspondiente valoración crítica. Recorrerlas brevemente nos permitirá ponderar la novedad de su método de composición mitopoético y de lectura analógica.

\section{1.b. Interlocuciones y lecturas}

La primera mención corresponde a Spengler, cuya influencia "deslumbrante" destaca por practicar la historiografía a través de los llamados "hechos homólogos": entre culturas diferentes, la existencia de símbolos equivalentes permite trazar comparaciones sobre la base de la morfología. Es así que la homología formal entre objetos pertenecientes a diferentes contextos históricos habilita el hallazgo de rasgos comunes. Como señala Horacio González, "Lezama se siente tocado por este pensamiento pero en el fondo lo rechaza" ${ }^{8}$. En efecto, si bien atraído por las analogías de Spengler, Lezama percibe que una lectura puramente formal de las homologías culmine finalmente en el pesimismo del eterno retorno. Lezama se va a oponer a esta lectura del corsi e ricorsi por redundar en una lectura de la historia que no ofrece novedad sino repetición. El paralelismo que Spengler encuentra entre culturas diferentes, fundado en la existencia de homologías, si bien no recusado, va a ser 'descongelado' por Lezama, como veremos, a través del llamado sujeto metafórico. Pues las resonancias que ese sujeto encuentra entre culturas distintas no redunda en el descubrimiento de una misma melodía sino que hacen aparecer lo distinto; nos entregan, por el chispazo de la contraposición, una visión nueva, diferente. Operativo por excelencia neobarroco: descongelar, devolver la tensión que pone en movimiento y que hace aparecer la chance de la reescritura de una nueva historia. Persistencia y repetición se combinan con novedad histórica, chispazo de las diferencias.

\footnotetext{
${ }^{7}$ Ibídem, p. 216.

${ }^{8}$ Ibíd., p. 9
} 
La importancia conferida al mito recae en la figura de T. S. Eliot. Para Eliot, en efecto, valerse del mito, tal como lo hace Joyce, es "una forma de controlar, de ordenar, de darle forma y significado al enorme escenario de futilidad y de anarquía que constituye la historia contemporánea" ${ }^{\prime}$. Pero desde la perspectiva de Eliot, dado que son los mitos antiguos los que estructuran los relatos, nada novedoso tienen los contemporáneos para ofrecernos. La tarea de los glosadores consiste pues en encontrar en esas raíces míticas el fundamento o la garantía de perennidad de lo actual, a quien sólo resta el juego fútil de las combinaciones. Eliot incurre así en el pesimismo de Splengler pero por otra vía. Y si bien Lezama no desdeña en absoluto el poder del mito en la construcción de las ideologías nacionales, el hecho de que se lo enseñe "en artificial aislamiento", es decir, que su narrativa eluda los nexos que lo unen a los mitos de otros pueblos, no hace más que fraccionar Europa "en una serie de entidades espaciales".

La renuencia de Lezama a aceptar la simple concatenación causal de los acontecimientos para su comprensión, implica el ingreso del historiador Arnold Toynbee a ese singular gabinete de lecturas, de quien valora el hecho de haber establecido veintiún tipos de civilizaciones ${ }^{10}$ sobre la base de un mismo conjunto de creencias básicas. Del historiador norteamericano resulta clave su lectura de la historia en base a estas unidades inteligibles fundadas en la imaginación de los pueblos. La fuerza inspiradora de la imago y de una minoría creadora son, tanto para Toynbee como para Lezama, la clave de inteligibilidad de una cultura y su capacidad de

\footnotetext{
${ }^{9}$ Al respecto, nos dice el propio Eliot comentando a Joyce: “Al valerse del mito, con el manejo continuo de un paralelismo entre lo contemporáneo y lo antiguo, Joyce adoptó un método que otros deberán asumir. No habrá imitadores, como sucede con los científicos, que se valen de los descubrimientos de Einstein para emprender sus propias investigaciones posteriores e independientes. Se trata simplemente de una forma de controlar, de ordenar, de darle forma y significado al enorme escenario de futilidad y de anarquía que constituye la historia contemporánea. Es un método del que ya había dado indicios W. B. Yeats, pues me parece que debemos considerarlo el primer poeta contemporáneo consciente de lo que ocurre. Es un método con un buen augurio en el horóscopo". Disponible en: https://es.scribd.com/document/281577425/T-S-Eliot-Ulises-Orden-y-Mito.

${ }^{10}$ Aunque Lezama mencione 21, hay 19 civilizaciones principales para Toynbee: Egipcia, Andina, China, Minoica, Sumeria, Maya, Indica, Hitita, Helénica, Occidental, Cristiana ortodoxa (Rusia), Lejano oriente, Cristiana ortodoxa, Persa, Árabe, Hindú, Mexicana, Yucateca y Babilónica. Hay también cuatro "civilizaciones abortadas" (Abortada del lejano occidente cristiano, Abortada del lejano oriente cristiano, Abortada escandinavo, Abortada siríaco) y cinco "civilizaciones confinadas" (polinesias, esquimales, nómadas, otomanas, espartanas).
} 
pervivencia: "Si una cultura no logra crear un tipo de imaginación, si eso fuera posible, en cuanto sufriese el acarreo cuantitativo de los milenios sería toscamente indescifrable ${ }^{\prime 11}$. Como vemos, la inspiración de Vico, a quien cita en más de una oportunidad, resulta innegable.

El último referente clave para el autor de Paradiso, tal vez el más influyente, es Ernst Curtius. Su erudito tratado Literatura europea y Edad media latina (cuya primera edición data de 1948) acerca de los nexos entre los clásicos y la literatura europea, unido a su fuerte sentido organicista de la cultura, parecen ejercer, según destaca Horacio González en un estudio introductorio reciente a la edición de los ensayos lezamianos, una poderosa influencia en su visión de la historia y en sus modos de abordaje. Es asimismo a través de Curtius que Lezama accede a un autor muy leído por aquél entonces y que recientemente vuelve a ocupar la atención de los estudiosos: Aby Warburg.

El acceso a algunos de los textos de reciente edición del autor de La pervivencia de las imágenes resulta iluminador a todos los efectos. Advertimos numerosos puntos de coincidencia entre el método de Warburg de lectura de la imagen y el de Lezama, en particular, la atención prestada a los detalles y el descubrimiento de analogías entre elementos que parecen accesorios. De modo que nexos sutiles, que no pasan por los 'grandes' motivos, entrelazan los clásicos con los modernos. Se desmonta asimismo la jerarquía implícita entre decoración, detalle y accesorio, pues es allí, en pliegues de vestimentas, cabelleras al viento o movimientos de manos, que descubrimos las semejanzas que vinculan lo nuevo al pasado. Lezama retoma así dos conceptos que van a ser centrales para el célebre historiador del arte: pervivencia (Nachleben) y fórmula del pathos (Phatosformel), de acuerdo con una traducción literal. Como veremos, Lezama resulta, en continente americano, un precursor a la hora de conferir a la imagen preeminencia en la formación de los imaginarios de los pueblos, cuya pervivencia en el tiempo contribuye a su gravitación. Por otro lado, no son las formas vacías (por eso rechaza a los formalistas) las que habilitan las vivencias, sino los afectos, las pasiones, los cuerpos. Por eso esos afectos configurados perviven. Y por

\footnotetext{
${ }^{11}$ José Lezama Lima, op. cit., p. 216.
} 
eso también es posible la contemporaneidad de todo lo presente y de todo lo pasado. Como Warburg, Lezama sienta a su mesa a Dante, al indio Kondori, a Martí, a Quevedo $^{12}$. Los convida a todos por igual; su textualidad sin comienzo ni fin es una urdimbre que entreteje lo heterogéneo, que fragua tiempos distintos y culturas por completo inasimilables pero que consigue, no obstante, enhebrar sin fusionar. Es el momento en que el sentido histórico de Nietzsche toma cuerpo en la lectura de la propia historia, jalonada hasta el momento por la ley fatal del desarrollo y por la pureza de las civilizaciones consideradas superiores: "A su vez, la historia dirige su atención al problema de cómo surgen las culturas; hace retroceder su mirada hasta las culturas prehistóricas; mide la duración de los sucesos humanos [...] e intenta deducir el número de culturas que tenemos por delante" ${ }^{13}$. Es el momento en que no sólo se descubre la importancia del tiempo, la historia y las genealogías, por las cuales "los movimientos culturales... pueden estar ligados por una relación de generaciones, de tal modo que una cultura pueda ser hija de otra", sino el poder modelador la fantasía y la imaginación, en el que comienza a percibirse la unilateralidad de los estudios limitados al Estado, y la pobreza de los análisis que sólo toman en cuenta el dato duro de las cifras y de los nombres propios. Lezama se hace eco de este modo de entrever la relación orgánica entre las culturas; sus constelaciones responden a este llamado a establecer lazos entre lo distinto, donde los padres no necesitan haber nacido en el propio suelo y las filiaciones limitarse a lo biológico. El gran legado de Curtius a Lezama es, pues, el de la contaminación de origen, en que las culturas se nutren de locales, invasores, bárbaros y sobrevivientes; son un mosaico que entremezcla lo distinto de manera única. Y es preciso tener oído para sintonizar y ser sensible a los contrapuntos que esta inmensa polifonía construye a lo largo de la historia.

Por último, señala citando a Ludwig Klages, es preciso tener memoria antes que recordar. La diferencia entre recuerdo y memoria resulta clave para el concepto de imago de Lezama: el recuerdo es obra del espíritu, pero la memoria lo es del alma. Se

\footnotetext{
${ }^{12}$ Nos dice F. Santos en su introducción: "Warburg es, a la vez, el erudito capaz de relacionar textos de distintas épocas y distintas culturas con las imágenes que tematiza, de incardinar sus indagaciones a marcos teóricos divergentes, el humanista inquieto, el positivista feliz...", en Aby Warburg, La pervivencia de las imágenes, Buenos Aires, Miluno, 2014, p. 23.

${ }^{13}$ Ernst Robert Curtius, Literatura europea y Edad Media latina, I, México, FCE, 1955, p. 23.
} 
tiene memoria por un ejercicio que es propio del ingenio, eso que los ingleses llaman Witz: capacidad de establecer analogías entre datos por completo divergentes. Por eso ciertas imágenes persisten, fundan eras. Esa capacidad para tejer enlaces entre elementos divergentes es la base del método analógico comparativista que Lezama propone para construir otra historia posible. Para superar el cansancio y el pesimismo de los partidarios del eterno retorno.

\section{1.c. Las bases del método: lejanía y vivencia oblicua}

"Sólo lo difícil es estimulante", nos dice Lezama apenas comienza el ensayo Mitos y cansancio clásico, anticipando un ejercicio que no se presta al fácil consumo, que es a la vez juego de seducción, posposición y retardo de una fruición que se dilata. "Es la forma en devenir en que un paisaje va hacia un sentido, una interpretación o una sencilla hermenéutica, para ir después hacia su reconstrucción que es en definitiva lo que marca si eficacia o desuso, su fuerza ordenancista o su apagado eco, que es su visión histórica” ${ }^{14}$.

El primer significante clave, pues, es "paisaje", que se conecta a "visión": una visión panorámica desde un cierto punto de vista. Como dirá luego en Las eras imaginarias, no son los acontecimientos o los hechos históricos, no son las batallas ni los grandes nombres los que signan las épocas, sino las imágenes. Lezama propone una filosofía de la historia en las que las diferentes eras son presididas por una imagen. Esa historia no tiene ni la concatenación ni las divisiones con que solemos aprehenderla. Las "eras imaginarias" se fundan en la potencia de metáforas que enlazan imágenes, no cosas, cortando de cuajo con la tradición aristotélica ${ }^{15}$. Esa toma de partido por la imagen nace de la pesadumbre y el dolor de la separación. Lezama parte platónicamente de la Forma esencial, de la que emanan cuerpos y seres. Destinados a la división, cuerpo y alma, espíritu y materia, eco y voz, procuran reestablecer los enlaces, evacuar el trauma y cerrar la herida. El objeto es lo más

\footnotetext{
${ }^{14}$ José Lezama Lima, op. cit., p. 211

15 En el mismo sentido se expide Jorge Luis Borges en su ensayo intitulado "Quevedo", con acostumbrada economía: "Olvidó, al censurarlas, que la metáfora es el contacto momentáneo de dos imágenes, no la metódica asimilación de dos cosas... “, Obras Completas, Buenos Aires, Emecé, 1974, p. 662.
} 
lejano, cuanto intentamos atraparlo, se nos pierde: una ruptura sin Mnemosine. La metáfora es entonces el procedimiento propiamente poético de acercamiento entre imágenes, huella de esa distancia. El poder de la imagen reside en su capacidad de sutura, es la encargada de reparar el tormento de la separación. Por eso, toda era imaginaria se halla presidida por la potencia de una imagen. No todas las imágenes alcanzan a proponer una época. Eso depende de su capacidad de engendrar una historia, de proveer símbolos significantes, de poner en la retina un signo eficaz, de marcar con una palabra sagrada. Para ello es necesario que esa imagen actúe en siglos o milenios, es necesario tiempo. El tiempo hace que esas imágenes se congelen y que luego se repitan, se fijen en el inconsciente de los pueblos. De este modo, el hecho imaginario, entrelazado con la imagen e investido por ella, se convierte en una "causalidad metafórica viviente". Lezama corta de cuajo con la causalidad lineal y con la distinción entre hecho crudo e imaginación, todo acervo de imágenes que persiste en el tiempo inaugura una era ${ }^{16}$.

Este breve rodeo por la cuestión de la imagen permite entrever la carga semántica conferida a 'paisaje', que sugiere una visión sobre la que se construirá esta interpretación singular de la historia, a la que concibe en términos de devenir. Nunca fija, la historia es materia maleable, depende del punto de vista, del ángulo de visión y de las conexiones, nunca definitivas, que puedan proponerse. Ello es obra del sujeto metafórico, sujeto capaz de tejer enlaces entre presencias naturales y datos de cultura, donde ninguno tiene preeminencia sobre el otro ${ }^{17}$. Esa relación sólo es posible por un

\footnotetext{
${ }^{16}$ Lezama desconoce la separación entre fantasías y realidad, lo que llamamos 'realidad' está realzado por la fantasía, enlazado con la imaginación. Imágenes fuertes fundan eras completas, pues son lo que engendra en modo viviente. En el ensayo Las eras imaginarias, señala que ellas son diez: la primera es la de idumeos, escitas y chimichacas, su imagen es el falo que crece como un árbol. La segunda es la egipcia y la pirámide como imagen de la muerte. La tercera es órfica y etrusca, su imagen es el fuego. La cuarta es la griega, con Parménides, la filosófica, la era de la ser, de la emanación, de la identidad. La quinta es la merovingia, su imagen es el rey como metáfora. La sexta es la taoísta y su poderosa imagen de la biblioteca. La séptima es la de la sangre, la de los aztecas. La octava es la de la piedra, la de los incas. La novena es la católica y su resurrección. La última es la de la revolución cubana, la de la pobreza irradiante. En esta última hay un nombre, José Martí. Martí poeta, figura de condensación de un pueblo pobre "rodeado por el milagro", por la espera. Milagro y espera del pobre. Es lo imposible actuando sobre lo posible, engendrando lo infinito en lo finito. Lo maravilloso y el sortilegio.

${ }^{17}$ En "Preludio a las eras imaginarias" (op. cit., p. 151) Lezama nos habla de dos tipos de enlace: el enlace causal (que se corresponde con la relación identidad-sustitución), propio del pensar moderno (donde Kant logra reconciliar lo incondicionado y lo condicionado) y el enlace que se da entre lo
} 
"contrapunto", término que encontramos disperso infinidad de veces en la ensayística lezamiana y cuya procedencia musical no escapa al lector atento: combinación de voces independientes que se unifican de manera simultánea para dar un efecto sonoro distinto, al que se da en Ilamar polifonía, en términos de Bajtín. Este tipo de síntesis armoniosa abunda en la literatura de Lezama, que consigue así, a través de fatigosas construcciones polifónicas, crear filigranas textuales donde lo distante se vuelve contemporáneo.

Pero vayamos a uno de estos ejercicios hermenéuticos, sin los cuales el método amenaza caer en palabrería vacía. Mitos y cansancio clásico comienza con dos pinturas: "Septiembre", de los hermanos Limbourg en El libro de las horas, de 1410 y "La cosecha" de Brueghel, pintura flamenca de 1565, en los que se nos ofrece dos formas de campesinado. Lezama dice entonces: comparemos. Pero no es una simple comparación para notar diferencias. No es poner una cosa al lado de otra de acuerdo con un criterio exterior, prefijado de antemano. Nos habla de "proyección retrospectiva" del segundo cuadro sobre el primero. La aclaración es importante porque indica una de las premisas de un método hermenéutico anclado en la inmanencia: no hay criterio exterior o pauta que derive de un sujeto que controle la escena, sino que es el roce o el choque de las pautas de construcción inherente a cada uno de los objetos de donde surge la diferencia que habilita la comparación. Su propósito es componer una determinada visión histórica a partir de la iluminación estilística, por la intervención de imágenes que encarnan formas diferentes de campesinado. Esta proyección retrospectiva como modo de conocimiento implica dos premisas: a) que se conoce una cosa a través de otra (conocimiento mediado); b) que ese conocimiento llega siempre después. O sea: demasiado tarde. No es conocimiento anticipatorio.

generatriz y lo generado, propio de la metamorfosis clásica (filosofía y mitología griega, aristotélica, ovidiana). Ambas se contraponen al azar y al sortilegio, que interrumpe cualquier tipo de conexión. A esas tres maneras de concebir la relación entre las cosas opone la transfiguración católica: conexión de imposible y posible, divino y humano, finito e infinito hecha posible en la imagen, "lo natural potenciado hasta alcanzar la cercanía con lo irreal" (p. 147). 
Luego tiene lugar el "contrapunto", operación de comparación que se establece entre series distintas. Si la primera serie tiene que ver la cosecha y los campesinos, la segunda trata de caballeros y cancilleres. Pasamos entonces del Retrato del canciller Rolin, del pintor Van der Weyden (1445), a la Madonna del Chancellor Rolin (1435), de Jan Van Eyck y al Retrato del caballero da fogliano, de Simone Martini (1328). Luego de una descripción minuciosa del semblante de los tres, y de una comparación conforme con elementos internos a cada uno de esos cuadros, refiriéndose al castillo que, en la serie sobre el campesinado, se insinúa por detrás, nos dice: "Parece como si en aquel estelar castillo... abriese sus lentas puertas". Y la arrogante confianza de los señores y embajadores evocados en los cuadros se hace presente. El contrapunto entre las series se establece a través del sintagma "puerta que se abre". Como hemos mencionado supra, el detalle hace su aparición, es él el que liga las series. Es en el elemento accesorio aparentemente fortuito donde se va a encontrar la lleve que permita tejer los enlaces ${ }^{18}$.

La expresión "puerta que se abre" es un "contrapunto animista". Detalle no menor: los objetos en el universo de Lezama están dotados de un alma. Es un universo en el que personas, objetos naturales y artificiales constituyen personajes que habilitan, a su vez, enlaces, relaciones. Valiéndose de las metáforas de persona que abundan en la literatura gongorina del siglo de oro español ${ }^{19}$, pero sin recurrir a ellas como un mero procedimiento o artificio retórico, Lezama dota de vida a objetos, artefactos, estilos. Ellos quedan investidos, a la vez, de esa gravedad propia del lenguaje castizo, por lo que, de allí en más, como lo hace a menudo en La curiosidad barroca, nos hable de "señor barroco":

En la Basílica del Rosario, en Puebla, donde puede sentirse muy a gusto ese señor barroco, todo su interior, tanto paredes como columnas, es una chorretada de ornamentación sin tregua ni paréntesis espacial libre. Percibimos ahí también la existencia de una tensión, como si en medio de

\footnotetext{
18 “ (...) de él [El nacimiento de Venus, de Botticelli] no es incorrecto concluir que el tratamiento de los detalles en movimiento fue tomado como criterio del 'influjo de la Antigüedad'", en Aby Warburg, op. cit., p. 57.

${ }^{19}$ Véase el §2. “Metáforas de persona”, en Curtius, op. cit., p. 193.
} 
una naturaleza que se regala, de esa absorción del bosque por la contenciosa piedra, de esa naturaleza que parece rebelarse volver por su fueros, el señor barroco quisiera poner un poco de orden pero sin rechazo, una imposible victoria donde todos los vencidos pudieran mantener las exigencias de su orgullo u de su despilfarro ${ }^{20}$.

El sintagma "puerta que se abre" inicia además la novela Oppiano Licario. Tenemos entonces un elemento más en nuestra constelación: una novela. Pero este no es cualquier objeto y la acción no es cualquier acción: es una puerta, un linde, un objeto que permite la conexión de un ámbito y otro, lo que abre y cierra, se entreabre... De aquí en más, la metáfora cobra vida propia y la puerta es vulva renuente, relación amistosa, mundo que aloja pero al que hay que preservar cerrando. El tejido lezamiano permite los más diversos entramados. Y siempre es un contrapunto el que hay que establecer, son dos, tres, cuatro elementos, que son los polos de la comparación.

El sintagma se encuentra a su vez en el I Ching. Es uno de sus hexámetros: "Puerta que se abre hacia afuera". De allí pasa, sin solución de continuidad, en una especie de carrusel que es frenesí barroco, contemporaneidad de todas las épocas, de todos los libros y especies, a la leyenda Taquea: entre las tribus ecuatorianas, Tacquea era el único jíbaro poseedor de la candela. Como la puerta de su casa estaba siempre un poco abierta, cuando los pájaros entraban Taquea los mataba, los aplastaba entre la puerta y el poste y se los comía. Esa puerta entreabierta es la razón por la cual el colibrí consigue robarle el fuego. El colibrí, nuestro Prometeo, es en verdad hombre metamorfoseado en pájaro, cuyo aleteo permite sortear el linde y el obstáculo interpuesto entre la naturaleza y la cultura.

Lezama construye así una disparatada polifonía entre cuatro momentos de la cultura: la de las tribus ecuatorianas, la china, la renacentista flamenca, la medieval. Presencias naturales y datos de cultura se entremezclan para dar una nueva visión, donde lo que importa -independientemente de la pertenencia de esos objetos,

\footnotetext{
20 José Lezama Lima, op. cit., p. 230.
} 
figuras, imágenes, a diferentes momentos y ámbitos culturales - es que nos proveen de una nueva visión y una nueva vivencia.

Esas llaves, que habilitan 'saltos' (por eso no hay gradación), amplían nuestra visión; lo fantástico se entrelaza con lo real. Es una visión de la historia que pasa por alto las causalidades habituales, pero no deja de lado los enlaces, al contrario: un mundo abre otro mundo, y esa visión, que pudiera ser disparatada, nos da la clave de la comprensión del presente, de nuestro mundo. Resumiendo: esas entidades naturales e imaginarias (culturales) no son impulsadas entonces por una causalidad exterior (a la que denomina "causalismo obliterado y ramplón"), sino por "enlaces". Y lo que permite su comprensión es su "contrapunto animista", su relación animada con otros. La tesis de fondo es que todo hecho cobra realidad y gravitación en el momento en que se lo une a la imaginación, o sea, en que queda convertido en imagen, que es la que les presta el hilado, la que permite tejer los enlaces.

Uno de sus más importantes biógrafos, Roberto González Echevarría, señala que Lezama basa su sistema en dos nociones: lejanía y vivencia oblicua. ${ }^{21}$ La esencia de lo poético no estriba pues en la proximidad de los objetos sino en la distancia que los separa. Cuanto más lejanos se encuentren entre sí los entes que aproxima, más acabado es el acto poético. De este modo, elementos de culturas y épocas dispares, separadas en el tiempo y espacio, encuentran una afinidad inesperada y sorpresiva. Obra del acto asociativo del sujeto metafórico que los hace entrar en cortocircuito separándolos de sus contextos habituales, éste es capaz de conseguir una aproximación iluminadora. La clave está en la distancia, no en la inmediatez. Esa fue la forma lezamiana de hablarnos de Cuba. Lezama describió a Cuba no en base de lo folclórico inmediato, o lo costumbrista, sino mediante un vasto universo de alusiones a culturas distintas, distantes en el tiempo y el espacio, lo que incluye incluso el mundo estelar. "Cuba es en Lezama tan rara como el Tlön borgeano..." "Es como si Cuba como si todo objeto de deseo, no pudiera ser observado de frente...". ${ }^{22}$ Lezama desdeña lo

\footnotetext{
${ }^{21}$ En Severo Sarduy, Obra completa, Tomo II, Edición crítica de Gustavo Guerrero-François Wahl Buenos Aires, Secretaría de Cultura de la Presidencia de la Nación, 1999 p. 1591.

${ }^{22}$ Op. cit., p. 1591.
} 
obvio, lo que se entrega sin resistencia. Así construye Paradiso, donde proyecta a Cuba pero a través del Dante. Son las mediaciones las que dan el acceso a las cosas. Es la fantasía la que constituye lo 'real', la ficción la llave de comprensión de lo próximo. El deseo, el rodeo por lo necesario.

\section{2.a. Severo Sarduy: retombée o causalidad acrónica}

Sarduy va a retomar este modo de leer de Lezama. Adopta el método comparativo (no en el sentido de que ambos elementos sean medidos a través de una regla, o una pauta, sino que uno es el que nos da el acceso al otro) y el de la correspondencia analógica. Pero no va a ser el detalle el elemento desde el cual establezca las analogías; no va a ser Warburg la fuente última de inspiración del método. La pertenencia del autor a Tel Quel, las lecturas de Barthes, Lacan, Foucault y Derrida lo imbuirán de parámetros posestructuralistas. Sin embargo, no es una analogía en que cada elemento mantiene con el otro una proporcionalidad equivalente; o que descansa en un espíritu que haría que todos los componentes de un sistema se hallen en armonía preestablecida, o que parte de una forma estructurante como origen y fundamento de todas las demás. Cada plano en Sarduy (cosmológico, corporal, escritural) es un eco del otro. O un reverberar. Esto es retombée o causalidad acrónica: los elementos resuenan entre sí sin que por ello sea legítimo establecer en el plano metafísico una dimensión que pudiera llegar a ser determinante de todas las demás; no sería legítimo trasgredir el plano de superficie o de expresión para ir a un más allá.

Sarduy va más lejos que Lezama en esto de establecer relaciones entre arte, ciencia, psicoanálisis, semiótica; entre la trayectoria de los astros (astronomía) y el diseño de una cúpula barroca, por ejemplo. Retorno a la agudeza del siglo de oro $^{23}$ : capacidad de establecer lazos, enlaces, prefiguraciones: "Retombée es también una similaridad o parecido, en lo discontinuo: dos objetos distantes y sin comunicación o

\footnotetext{
${ }^{23}$ En relación con la agudeza como capacidad, no llamada a reflejar la realidad de manera mimética o a replicar el sentido común, sino como experiencia de libertad y espontaneidad, propia del llamado 'conceptismo' del Siglo de oro, véase Jon Snyder, La estética del Barroco, Madrid, La balsa de la medusa, 2014.
} 
interferencia pueden revelarse análogos; uno puede funcionar como doble de otro, no hay ninguna jerarquía de valores entre el modelo y la copia" ${ }^{24}$. Retombée implica, pues, isomorfismo: formas análogas entre la cosmología, la ciudad (que es equivalente al orden político), la anatomía corporal y las artes; entre orden científico y orden simbólico. Una correspondencia secreta entre cuerpos celestes, carnalidad biológica (humana y animal) y cosmos escritural, que es donde se halla la cifra o la llave para el acceso a las demás dimensiones, sirve de argamasa del todo. Es en la retórica -que es también una erótica: allí donde tiene lugar el deseo- donde se encuentra la clave que permite entender el todo. En "Nota" (capítulo que inaugura el ensayo Nueva inestabilidad) y "La desviación de los cuerpos que caen", nos dice:

No se trata de presuponer... El reflejo o la retombée que una cierta cosmología pueden suscitar en el campo artístico, o viceversa. Si hay una relación de oposición o de analogía, esta no funciona más que descifrando, tondouno con respecto a otro, cierto tipo de figuración y cierto modelo cosmológico ${ }^{25}$.

Se trata, ante todo, de desciframiento. Y ese desciframiento, el hallazgo de la cifra y de la medida, tiene lugar cuando una cosa se pone junto a la otra ("uno con respecto a otro"); es la oposición lo que descubre las 'formas de lo imaginario', las 'maquetas', los axiomas intuitivos que, siguiendo a Foucault, caracterizan la episteme de la época ${ }^{26}$.

"No se trata de presuponer"... La consigna es primordial: no se trata de presuponer un orden a priori de las cosas, una forma fundamente, un origen o una determinación. Como en Lezama, no se trata de la Forma formante platónica que homologa lo distinto. En el orden del conocimiento, el descubrimiento de la cifra que signa una época resulta del frotamiento de dos o más elementos, de la chispa que surge de su contraposición, en la que una puede servir de marca de la otra: una trayectoria astronómica puede ser la marca del diseño de las cúpulas de las catedrales.

\footnotetext{
${ }^{24}$ En “Nueva inestabilidad” (1987), ibíd., p. 1370.

${ }^{25}$ Ibíd., p. 1347.

${ }^{26}$ Michel Foucault, Las palabras y las cosas, México DF, S. XXI, 1993.
} 
O viceversa: el tondo o el marco pueden ser la marca de que una manera de concebir el cosmos está en marcha y lo impregna todo. La ausencia de nexo metafísico entre causa y efecto hace, una vez más, que toda comprensión sea retrospectiva: sólo el efecto nos 'da' la causa; pero esa causa no estaba allí antes, en potencia, sino que puede ser puesta por el efecto (la copia 'pone' el original, o lo que presuntamente llamamos copia proyecta el origen: es a través de la figura del travesti que podemos capturar la 'esencia' de la mujer). La causa es un eco del efecto y no al revés.

\section{2.b. Prebarroco, barroco y neobarroco}

Habría entonces, de acuerdo con el método, tres grandes eras imaginarias (pues en las que la matriz estructurante es siempre una imagen o figura): el prebarroco, el barroco y el neobarroco, cuyo desarrollo ocupa el ensayo Barroco.

En el prebarroco encontramos a Copérnico, Galileo, Bruneleschi y Rafael: preeminencia del círculo, degradación de la materia, geometrización del espacio, idea de movimiento natural. Como efecto de esa cosmología, la representación del espacio se hace ordenada, se inventa la perspectiva. Es pues, un universo conservador, monoteísta, logocéntrico, en el que centro y sentido son únicos. También la ciudad prebarroca se ordena en torno a un centro de acuerdo con el modelo armonioso del cuerpo humano.

En cambio, el orden cosmológico del barroco es la elipse. Ya no hay centro único, hay una topología descentrada, una apertura infinita. La elipse es estructura y también figura: por eso puede transponerse al espacio semiótico. Sus equivalentes en pintura son Caravaggio, El Greco, Rubens, Borromini, Velásquez, Góngora, Holbein, en particular, Los embajadores ${ }^{27}$. El espacio de la representación descansa en el

\footnotetext{
${ }^{27}$ Aquí Sarduy no opera como Lezama, no va a comparar un cuadro con otro. Su mirada se va a mantener al interior del cuadro donde lo que se comparan no son objetos sino modos de mirar. No cosas sino perspectivas y puntos de vista. Ellos colisionan al interior de lo mismo. Son diversos y hay que encontrarlos. Son diversos y están en nosotros, sólo que no lo sabemos. La práctica de la interpretación predispone al desplazamiento, al cambio de perspectiva. Hay entonces dos vertientes de ese barroco fundador: uno, el representado por los embajadores: en la anamorfosis -que añade siempre un suplemento de información (con frecuencia alegórico) - habría una pretensión didáctica: frente a la imagen vista de frente, la concha marina engañosa prueba con el desplazamiento, el fasto vaciado. Pero
} 
descentramiento. La ciudad barroca se concibe como una trama abierta. Lo propio es la doble focalización, lo cual introduce la cuestión del doble, lo duplicado, el reflejo, el espejo, el doble punto de vista (anamorfosis).

Ahora bien, ese doble, ese espejo, en el neobarroco, va a ser siempre un espejo deformante, un rictus, una parodia. Un laberinto de espejos en el que las imágenes resultan multiplicadas, diseminadas, pulverizadas. El orden cosmológico del neobarroco es el big bang y sus correspondientes en pintura: Portacarrero y Abreu. Hay una isomorfía entre esa teoría y la nueva configuración simbólica. Es lo que muestran las páginas de Nueva inestabilidad: la sobreabundancia y la proliferación, el oro y el exceso van hacia un estado de desequilibrio, de trastorno, de desintegración, de diseminación y de fractura. El neobarroco es reflejo deformante de una entropía.

Esta teoría del reflejo deformante se complementa con la teoría de la artificialización y el carnaval, el artificio y la fiesta: si el cuerpo es reflejo del cosmos pero es un reflejo que distorsiona el original, entonces el cuerpo se engalana, se afeita, se maquilla, se enjoya y metamorfosea ${ }^{28}$. Se traviste. Hay un proceso de subversión por el que la copia termina por resultar ajena al original, lo sustituye, lo neutraliza, lo deja fuera de juego. Lo mismo sucede a nivel del lenguaje: la escritura neobarroca no pretende imitar ninguna realidad, no es copia que degrade sino que es producción metonímica de significantes sin orden y ley, en el que el significante principal brilla por su ausencia, de ahí las enumeraciones, yuxtaposiciones, perífrasis. Es proliferación desordenada. ${ }^{29}$

¿Dónde encontrar en esta sobreabundancia la cifra del universo, donde encontrar la llave, las puertas que se abren? La marca está en los cuerpos. Se trata de encontrar el diagrama que articula cuerpos celestes, cuerpo textual, cuerpo biológico intervenido, tatuado o tajeado. En todos ellos hay una marca que permite transitar de

la calavera también se superpone al paisaje que intenta destituir. Sobre posición que revela en modo oblicuo, pero reveladora al fin. La 'verdad' es la vanidad, la banalidad, la muerte, el sinsentido, la nada]. ${ }^{28}$ Rodríguez Monegal, Emir: “Sarduy: Las metamorfosis del texto", en S. Sarduy, op.cit., 1974, pp. 17341750.

${ }^{29}$ Barrenechea, Ana María: "Severo Sarduy o la aventura textual”, en Severo Sarduy (1999), op. cit., 1978, pp. 1763-1770. 
lo cosmológico a lo semiológico. Se trata entonces de pasar del cuerpo celeste al cuerpo terrenal en que se inscribe la errancia de unos astros prestos a la dispersión. Esos cuerpos reproducen la fuga de la irrupción original, la que da origen al tiempo y al espacio. Cuerpos fugados (exiliados de su tierra y de sí mismos), prestos a las más variadas trasmutaciones, anulando el binarismo de los géneros pero al mismo tiempo confirmándolo, implosionando sobre sí como las enanas blancas, incandescentes como los soles.

La marca está en la escritura. Ese es 'el' cuerpo de la escritura al que se somete a torsiones, retorcimientos, que es palimpsesto y tatuaje, que reproduce citas, se cita a sí mismo, replica parágrafos que vuelven a repetirse pero que suenan distintos y al mismo tiempo son un deja $v u$, engranajes de una maquinaria que canibaliza al propio autor, que aparece incrustado en la novela, sometido a sus exigencias, siendo efecto de una escritura que adquiere autonomía ${ }^{30}$. El isomorfismo sarduyiano alimenta pues esa correspondencia invisible que no excluye la discordia, y que se expresa tanto en los planos cosmológico y semiótico. Ninguno tiene relevancia sobre el otro, porque al inscribirse en la superficie, al formar parte de un régimen de inmanencia, cada cual incide sobre el otro e inspira ese gesto que hunde tajeando o eleva, genera la ilusión de una profundidad misteriosa o de una inalcanzable trascendencia.

\section{Conclusión}

Hemos visto cómo en José Lezama Lima 'distancia' y 'vivencia oblicua' constituyen el modus operandi de su sujeto metafórico. De él resultan tanto el método de composición denominado mitopoético, como el método hermenéutico comparativo sin pauta exterior en tanto dispositivo de lectura y reescritura. Pero ese sujeto es también 'resultado', pues el autor es un efecto o un eco, un reverberar. De acuerdo con dicho dispositivo, los enlaces y las constelaciones, surgidos de la agudeza, acercan

\footnotetext{
${ }^{30}$ Como observan Ulloa y Ulloa (1999), el significante clave es 'cuerpo'. Su tratamiento incluye tres sentidos: a) cuerpo como espacio de inscripción y texto escrito, en el que la piel es pergamino y membrana; b) cuerpo como vestidura, como saco de vísceras, en el que las partes pueden cobrar autonomía en tanto fragmentos de un no-todo (pies, cabellos, cráneo); c) cuerpo como fuente de placer y también de dolor y muerte (cuerpo enfermo, cuerpo desecho, cuerpo mártir). Ulloa, Leonor y Ulloa, Justo (1999) "La obsesión del cuerpo en la obra de Severo Sarduy", en S. Sarduy (1999), Obra completa, Buenos Aires, Secretaría de Cultura de la Nación, pp. 1626-1643.
} 
lo lejano y tornan contemporáneo lo distante. De este modo, Lezama construye una compleja polifonía en el que la textualidad se concibe como contaminada, impura y susceptible de metamorfosis, presta a cambios no recurrentes, reacia a las repeticiones, no a la pervivencia: la persistencia de ciertas imágenes, como se ha visto, funda eras completas. Lezama es un adelantado, en América Latina, en relación a la importancia y la performatividad de la imagen, como pre-formadora de maneras de 'ver' el mundo.

Si bien no es sencillo hallar la puerta que se abre o el pasadizo que lleva de uno a otro, el concepto de retombée de Sarduy retoma esta idea: aún procedente de un plano diverso, el eco de una trayectoria lunar puede hallarse en el diseño de un cuadro o en la planta de un edificio. Pero la isomorfía no decanta en la igualación del distinto, pues lo que se replica o reverbera añade siempre un suplemento, un elemento de distinción o distorsión. Esta hermenéutica sugiere entonces una secreta correspondencia que, en el momento neobarroco, exaspera ese doble movimiento: deformación y exceso, proliferación y despilfarro. El momento disruptivo neobarroco tiene lugar, específicamente, en el plano del lenguaje, de la morada del ser: es él el que se enrosca, se afeita, se traviste. Reflejo deformante, carnaval, artificio y fiesta, el cuerpo del texto refleja el cosmos. Pero es un reflejo que distorsiona el original, que se metamorfosea y traviste. Hay entonces un proceso de subversión por el que la copia termina por resultar ajena al original, lo sustituye, lo neutraliza, lo deja fuera de juego. La escritura neobarroca no imita ninguna realidad, no es siquiera copia que degrade: es producción metonímica de significantes que proyecta su propio original o que torna ausente el significante principal haciéndolo presente sin nombrarlo. Las enumeraciones, yuxtaposiciones y perífrasis decantan en una escritura que es proliferación desordenada.

A nivel ya no de la escritura sino de la estructura narrativa, tanto en Lezama como en Sarduy desaparece la posibilidad de un punto de vista exterior o neutral: en Lezama es un plano el que descubre por contraposición la potencia del otro; en Sarduy, la correspondencia secreta entre los niveles desvanece la posibilidad de un fundamento, pues cada uno es el eco del otro, sin que ninguno se ofrezca como 
resorte originario o estructura determinante del no-todo. Operando en distintos planos, diseminando los puntos de vista, el lector que construyen (pues texto, autor y lector no existen a priori) no puede ser otra cosa que un nómade, un peregrino que deambula sin un itinerario fijo y sin hoja de ruta. Pero no es tampoco que carezca de recursos ni de criterios: la vivacidad de su imaginación, su capacidad de tejer enlaces lo habilitará para formar comunidad, para hacer de los otros (presentes, pasados) sus contemporáneos. Para hacer del sí-mismo un otro. Ello ofrece la posibilidad de una hermenéutica, no como des-ocultación o des-encriptación de sentido, sino como entramado de nuevos sentidos en el que la alternativa a la revolución, o mejor, la otra revolución, se presenta como revuelta del cuerpo propio, del cuerpo comunitario y del cuerpo textual. No contrarreforma sino contraconquista.

\section{Bibliografía}

Borges, Jorge Luis. Obras Completas. Buenos Aires, Emecé, 1974.

Curtius, Ernst Robert. Literatura europea y Edad Media latina. México, FCE, 1955.

Eliot, Thomas Stearns. "Ulysses, Order and Myth". The Dial, LXXV, Nov. 1923. Disponible en castellano en https://es.scribd.com/document/281577425/T-S-EliotUlises-Orden-y-Mito

Lezama Lima, José. Ensayos barrocos. Imagen y figuras en América Latina. Buenos Aires, Colihue, 2014.

Lezama Lima, José. Oppiano Licario. Madrid, Cátedra, 1989.

Lezama Lima, José. Paradiso. Buenos Aires, ediciones de la Flor, 1968.

Rossi, María José. "La errancia como método: la noche de Jacques Rancière". Nuevo Itinerario, Revista digital de Filosofía, Septiembre 2017.

Sarduy, Severo. El barroco y el neobarroco. Buenos Aires, Cuadernos del Plata, 2011.

Sarduy, Severo. Obra completa. Edición crítica de Gustavo Guerrero-François Wahl Buenos Aires, Tomos I y II. Buenos Aires, Secretaría de Cultura de la Presidencia de la Nación, 1999.

Snyder, Jon. La estética del Barroco. Madrid, La balsa de la medusa, 2014.

Warburg, Aby. La pervivencia de las imágenes. Buenos Aires, Miluno, 2014. 